\title{
Influence of Behavioural Economics and Psychology on Consumer Decision Making Process in Marketing Communication
}

\author{
Eva Kretiková, Veronika Fašková \\ Faculty of Mass Media Communication University of SS. Cyril and Methodius in Trnava, Trnava 91701, Slovakia.
}

\begin{abstract}
This paper adverts to selected behavioural economics and psychology appeals applied in marketing communications and their influence on consumer decisions making process and behaviour. It provides theoretical basis supported by arguments from the fields of marketing, psychology, economics and neuroscience. The goal of this paper is to point out the influence of economical and psychological appeals on consumer decision making process.
\end{abstract}

Index terms - consumer decision making process, psychological appeal, behavioural economics, marketing communication

\section{Introduction}

Marketing communication, consumer behaviour and decision making process are all essential parts of marketing. To be able effectively define and understand marketing, thorough understanding of its cooperation with other fields of science is needed, as well as its scientific qualities in manipulative communication with customers. Marketing cooperates with sciences such as neuroscience, neuromarketing, psychology and last but not least, behavioural economics.

Consumer behaviour is influenced by various factors cultural, sociological, personal, economical and psychological. The decision making process of consumers itself is influenced by various types of factors as well, at which there are various models of shopping models in existence [1]. Marketing is based mainly on knowledge of human needs. The Need can be defined as conscious or unconscious feeling of lack [2].

In this case it is necessary to say that the human meets the most important needs first. When they are satisfied, cease to be human motives and he tries to satisfy the following urgent needs (Maslow theory). On the other hand Freud theory says that human cannot realize their motivation. This is one of the cases when is needed the marketing research [3].

A consumer behaviour affected by the oldest part of brain called reptilian brain is based on the irrational and unconscious decision-making processes of customers. Knowing the human brain and motivation of customers, we are able to set a target group suitable form of marketing communication. To innovate traditional marketing and marketing communications [4] we could though more incentives or appeals.

"Innovations try to change the status quo, which is why markets resist them! A market's hostility to innovations becomes stronger when market players are interconnected; each player will switch to a new product or service only when s/he believes others will do so, as well. To be successful, innovators have to realize system-wide switch of their business behaviour to create environment, where many would adopt their innovations and believe they are better off because of it. It is feasible only if innovators master the process of knowledge transfer within their innovation activities. More than 50\% of promising and good prepared innovation activities fail. Not due to organizations' weaknesses in technology or organization, but due to their inability to handle properly the social and psychological aspects of processes which deal with the innovation's solution [5]".

A question of great importance within marketing communication is how the end of customer reacts to stimulus utilised by the enterprise. The marketing question occupies a central position as end consumers react to different marketing incentives to enterprise use. An enterprise who understands how consumers will react to different variants of product, price and marketing communication tools have a significant competitive advantage. Therefore, enterprises attach importance to the understanding of the relationship between stimuli marketing and consumer behaviour [6].

We count that our world and marketing change today. Human social activities, behaviours, and social structures and social processes have moved from real world to virtual world. New concepts, theories, and paradigms have been emerged as a result of the new virtual comer [7].

\section{Relativity and Bait Pricing Influence on Consumer Decision Making Process}

One of the factors influencing creation of market supply of goods or services is price, which has impact on consumer decision making process. Adequately formulated offer is of the same importance in relation to success of particular product communication. There are several definitions widely accepted in marketing, which claim that price influences service and product demand, because consumers make decisions are rational and when given the choice of two or more prices, they naturally choose the lowest one. Integration of knowledge from psychology, behavioural economics and that of marketing can help us easily manipulate consumer decision making process, leading to a finding that this process is $90 \%$ irrational, hence unconscious.

There are several ways of influencing consumer decision making process based on knowledge from other fields of science. The principle of relativity and bait, which will be discussed in this paper, determines irrationality of human decisions and high rate of influenceability. This principle is 
widely used in teleshopping or printed advertising, aiming not only for getting the consumer to buy something, but to buy a particular, well defined service or product. The principle of relativity can be explained on this simple example.

Question: The picture below shows two lines. Which one of these two is longer?

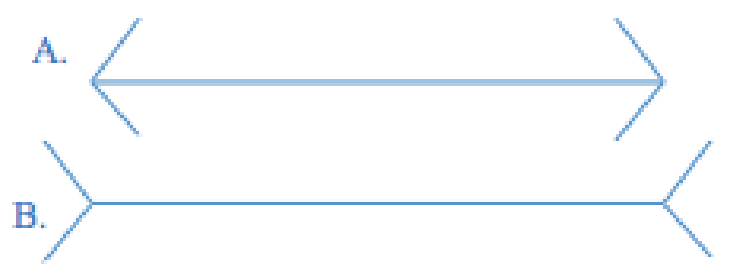

Answer: Despite the line B being seemingly longer than the line A, they are both of the same length.

Relativity is a state, which makes something appear to be different (more advantageous in decision making process), than it is in reality. Actually it serves as a nice example of how our brains operate. People, customers, consumers always perceive a thing only in relation to its environment. This principle is as valid for products and goods as it is for services and experiences in ever day life, where the most usual comparison is between the new and the old flat, or this year's holiday and the one we took last year [8].

"Marketing communication is in its closer understanding focused on targeted activities of particular entrepreneurial entities on the market, which lead to satisfaction of entrepreneur's needs on the one hand and those of a customer or a consumer on the other [9]."

Chart No.1 shows the use of traditional offer marketing communication of two products (A \& B), where both products correspond with two different attributes. One of the attributes can be price, the other can be quality. Since both products have their advantages, it is hard for a customer to decide which one is better. Consumers make their decision based on the principal of attribute comparison of products or services. The decision in this case would not be an easy one, since one of the products is cheaper the other one is of better quality. Comparison in daily life situations happens usually when products or services are displayed next to each other and are compared easily, for example by looking at one particular attribute of both items. On the contrary, customers often avoid comparing things, when deeper analysis is needed, as seen on chart No. 1.

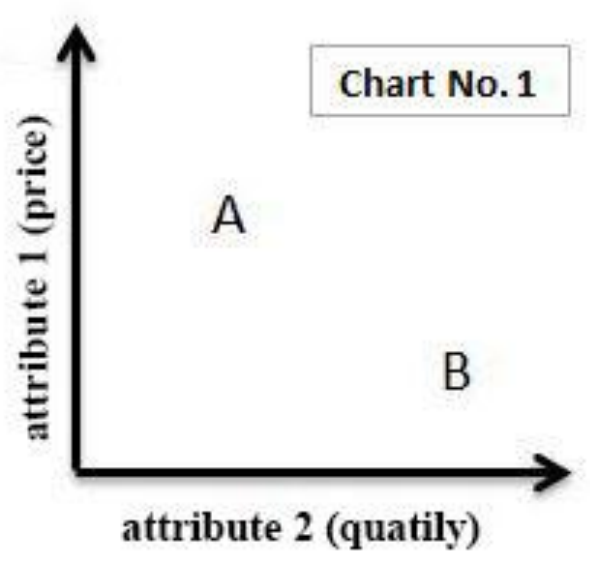

Chart No.1 The traditional offer marketing communication.

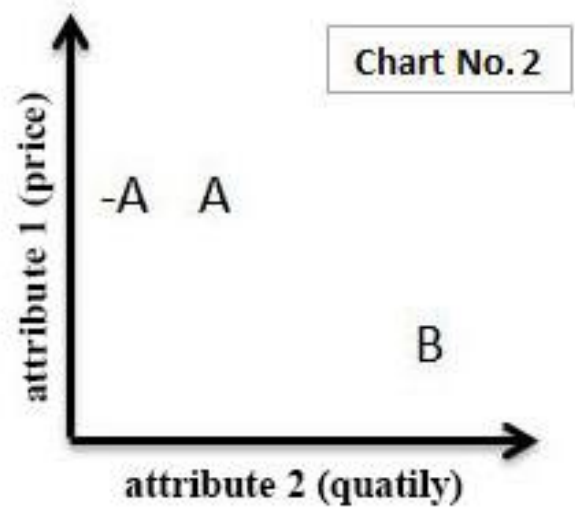

Chart No.2 The usage of bait (-A) in marketing communication.

Chart No. 2 shows the use of bait in marketing communication. Since this bait is price related, we can identify the influence of behavioural economics as well as psychology on customer. By adding another option (-A) to the original offer (see chart No.1), bait has been created, which will help persuade the customer make a purchase preferred by us. In principle, we have stimulated human indecisiveness and by adding the third option created an opportunity for the customer to compare two similar offers. As seen on the chart, the offer A is similar to the offer (-A), however (-A) is a little less advantageous. By creating baits (-A), we have offered room for fictitious comparison and have therefore influenced consumer's decision making process to choose offer (A).

\section{Situation Model of Psychology and Behavioural Economics Use in Marketing Communication}

We face appeals of psychology and behavioural economics in everyday life. Following the appeals together with relativity and bait effects from the previous chapter, we have decided to create a situation model, which will simultaneously serve as a test of this paper's readers in real life. 
Imagine this situation model No. 1 and try to answer for yourselves what your reaction would be.

You like a particular magazine which you have decided to subscribe for, for a year. The back cover of the magazine shows subscription options, as visible below. Which option would you choose?

- Online version of the magazine - $19 €$

Online access to full version of the magazine for a period of 12 months, including archive of previous editions!

- Print version of the magazine $-89 €$

Printed magazine for the period of 12 months, with home delivery included!

It is relatively simple choice, since we compare two options of the same product - subscription to electronic version for $19 €$ for 12 months or subscription of the same magazine in printed form for $89 €$ for 12 months. Anyhow, all we care about is the information the magazine offers us. Therefore our tip in this case is, you would choose online subscription of the magazine for $19 €$.

Imagine another situation model No. 2, based on the same principle.

You have decided for a 12 month subscription of a magazine you like. However, this time there are different subscription options. Which one would you choose?

- Online version of the magazine - $19 €$

Online access to full version of the magazine for period of 12 months, including archives of all the previous editions!

- Print version of the magazine $-89 €$

Printed magazine, with 12 month home delivery!

- Print and online version of the magazine $-89 €$

Both, printed magazine and online version of it for period of 12 months!

Of course, archive of all the previous editions online and this year's editions comfort home delivery.

We could not be sure what option you would choose in the first situation model, however we can be $100 \%$ sure you would choose the third option in the second situation model print and online version of the magazine for $89 €$.

\section{Conclusion}

The customer has the possibility of choice between two offers, particularly between two offers of subscription in the first model, which differ in price and features. The offer A (online subscription) is cheaper, but less convenient compared to the offer B (print subscription) - home delivery. Despite living in the age of electronics and the Internet, it was not easy to estimate which of the two offers would be more preferred among possible customers.

To make the decision process easier for you and to achieve desired effect (choosing the more expensive option), we have created "bait" in the form of offer C, as seen in the model situation No.2. Thanks to introducing a third option (C) the chances of an option seemingly more convenient than the other two being chosen increased immensely. However its price is identical with that of the offer B. The quality of this offer is only slightly higher than compared to the others.

Despite feeling you were making a rational and conscious decision, your decision making process was strongly influenced by the offer $\mathrm{C}$ and relativity thanks to adequately applied knowledge from the field of psychology and behavioural economics in marketing communication. You decided irrational and unconsciously.

Finally, the paper is important to ask the question that answers to several authors, as well as J. Matúš: What are the real reasons of well-considered media manipulation?

One of the most answers of this question is what J. Matús said: At present, the strategy in media is similar. In the information times, the most important for the elites is to turn attention of the masses off of real problems and to overwhelm them by entertainment industry. The point is the same - people should not think, but conform to 'certain interests' and buy [10].

\section{Acknowledgment}

The paper is a part of research project VEGA 1/0283/15 named: Aspects of marketing communication in area of process creation customer's value on B2C market in context with maximization of market share in retail gravity.

\section{References}

[1] V. Pizano, E. Kretiková, A. Bobovnický "Prípadové štúdie z marketingu" Trnava : FMK UCM, 2014. pp. 60 - 100.

[2] J. Matúš, K. Ďurková, L. Č́byová "Marketing - základy a nástroje" Trnava : FMK UCM, 2008. pp. 100 - 284.

[3] J. Matúš, K. Ďurková, L.Č́ayová "Moderný marketing” Trnava: FMK UCM. 2012. pp. 74 - 77.

[4] L. Čábyová, J. Ptačin "Benchmarking Comparison of Marketing Communication of Universities In Slovakia" Communication Today, 2014, Vol. 5, No. 1. Trnava: FMK UCM v Trnave, 2014. pp. 54 - 66.

[5] A. Zaušková, Z. Pitra "COMMUNICATION IN KNOWLEDGE Transfer Management" Communication Today, 2014, Vol. 5, No. 2. Trnava: FMK UCM v Trnave, 2014. pp. 50 - 64.

[6] J. Matúš, K. Ďurková, L'Č́ábyová "Moderný marketing" Trnava: FMK UCM. 2012. pp. 74 - 77.

[7] D. Al-Badayneh "Human behavior when and where virtual society meets physical society?" European Journal of Science and Theology, February 2013, Vol.9, No.1. Romania: ECOZONE Publishing House, 2013. pp. 105-110.

[8] D. Ariely "Jak drahé je zdarma" $1^{\text {st }}$ ed. Praha : Práh, 2009. pp. 1 - 40.

[9] A. Kusá, V. Pizano "Marketingové analýzy a stratégie" Trnava: FMK UCM in Trnava, 2011. pp. $40-150$.

[10] J. Matúš "Media and Culture" European Journal of Science and Theology, October 2014, Vol.10, Suppl.1, Romania: ECOZONE Publishing House, 2014. pp. 93-98. 